\title{
Colletotrichum Species Related To "Nam Dork Mai See Tong" Mango In Central Thailand And Risk Detection of Carbendazim-Resistant Strains
}

\section{Santiti Bincader}

Kasetsart University Faculty of Agriculture at Kamphaengsaen

Ratiya Pongpisutta ( $\nabla$ agrryp@ku.ac.th )

Kasetsart University Kamphaeng Saen Campus https://orcid.org/0000-0003-4161-4597

Chainarong Rattanakreetakul

Kasetsart University Faculty of Agriculture at Kamphaengsaen

\section{Research Article}

Keywords: Colletotrichum, Fungicide resistance, Mangifera indica, PCR-RFLP

Posted Date: August 19th, 2021

DOI: https://doi.org/10.21203/rs.3.rs-782870/v1

License: (c) (i) This work is licensed under a Creative Commons Attribution 4.0 International License.

Read Full License 
2 Title:

3 Colletotrichum species related to "Nam Dork Mai See Tong" Mango in Central Thailand and Risk Detection of

4 Carbendazim-resistant Strains

5

6 Author information:

$7 \quad$ Affiliations

8 Department of Plant Pathology, Faculty of Agriculture at Kamphaeng Saen, Kasetsart University, Nakhon 9 Pathom 73140, Thailand.

10 Santiti Bincader, Ratiya Pongpisutta \& Chainarong Rattanakreetakul

11

Postharvest Technology Innovation Center, Ministry of High Education, Science, Research and Innovation, 13 Bangkok 10400, Thailand.

14 Santiti Bincader, Ratiya Pongpisutta \& Chainarong Rattanakreetakul 15

\section{Essential title page information}

5

\section{Santiti Bincader}

E-mail: $\underline{\text { Santiti.bi@ku.th }}$

ORCID ID: 0000-0003-2427-5394

Ratiya Pongpisutta

Email: agrryp@ku.ac.th

ORCID ID: 0000-0003-4161-4597

Chainarong Rattanakreetakul

Email: crattan99@yahoo.com

ORCID ID: 0000-0003-4616-0619

\section{Corresponding author:}

Correspondence to Ratiya Pongpisutta

Tel: +66 34 351890; Fax: +66 34351890 


\section{Colletotrichum species related to "Nam Dork Mai See Tong" Mango in Central Thailand and Risk}

\section{Detection of Carbendazim-resistant Strains}

\section{Abstract:}

Nam Dork Mai See Tong mango is a deluxe commercial fruit in Thailand, however anthracnose disease becoming a major problem affecting market-driven. Fungicide treatment is the main component in the mango anthracnose management, notwithstanding the appearance of fungal-resistance has been become a factor of fungicide limition and can affect to increasingly higher costs. Thirty-two isolates of the Colletotrichum species complex were obtained from anthracnose-diseased mango cv. Nam Dork Mai See Tong in 3 provinces of Thailand. Fungal identification based on morphological and molecular markers was investigated. All isolates were divided into 3 species: C. asianum, C. gloeosporioides and C. siamense. Pathogenicity tests revealed that all 3 species caused symptoms on artificially unwounded mango fruits and leaves. Only C. gloeosporioides have previously been reported on mango, while $C$. asianum and $C$. siamense were first reports associated with mango in Thailand. The responsiveness of Colletotrichum isolates to carbendazim was evaluated using an MIC assay. Nine isolates of $C$. asianum were highly resistant, while 5 and 8 isolates of $C$. gloeosporioides were resistant (R) and highly resistant (HR), respectively. Moreover, all isolates of $C$. siamense were HR. Mutations were detected by PCR of a partial sequence of the $\beta$-tubulin gene. The sequence of $\beta$-tubulin gene in HR strains showed a single nucleotide transversion of adenine to cytosine, resulting in a substitution at codon 198. However, R strains were found to have only an amino acid change at codon 200. Additionally, PCR-RFLP was applied as a rapid technique to detect carbendazim resistance. The results demonstrated that only the $B s h 1236$ r restriction enzyme generated two bands (200 and $300 \mathrm{bp)} \mathrm{in} \mathrm{the} \mathrm{highly} \mathrm{resistant} \mathrm{strain,} \mathrm{but} \mathrm{these} \mathrm{bands} \mathrm{were} \mathrm{absent} \mathrm{in} \mathrm{the} \mathrm{sensitive} \mathrm{(S)} \mathrm{and} \mathrm{R} \mathrm{strains.}$ Hence, PCR-RFLP technique showed the potential to specifically detect benzimidazole fungicide resistance in 3 species of Colletotrichum. Moreover, this technique is accessible and feasible for laboratory assessment.

\section{Keywords:}

Colletotrichum; Fungicide resistance; Mangifera indica; PCR-RFLP 


\section{Introduction:}

In 2018-2019, world mango production expanded to more than 100 countries, with more than 44,626,000 tons of fruits produced annually. Thailand is one of the top three mango-producing areas, producing almost $7.69 \%$ of global mango production, and approximately $2 \%$ of fresh mango fruit is exported (Worldatlas 2019). Anthracnose disease caused by the genus Colletotrichum is one of the crucial problems occurring in field, along with postharvest diseases, and affects mango quality in Thailand (Walker et al. 1991). The mango cv. 'Nam Dork Mai See Tong' is highly susceptible to disease and can be affected by a latent infection during transportation (Sangchote 1987). The infection occurs via an appressorium that develops from germinating spores on the plant surface followed by turgor pressure penetration in the cuticle and, in some cases, infection of the epidermal cells by infective hyphae.

The studies of genus Colletotrichum on mango have been reported and classified into many different species such as $C$. acutatum species complex, $C$. boninense species complex and C. gloeosporioides species complex (Damm et al. 2012a, b; Weir et al. 2012). Previously, Colletotrichum species complex has been identified using morphological markers and ITS sequences but sometimes the ITS-region information alone is insufficient to distinguish closely related taxa. Hence, ACT gene, CHS-1 gene including TUB gene were used to clarify for species identification in the genus Colletotrichum, accurately. Moreover, species identification of fungal plant pathogen will lead to decide chemical fungicides for protecting and controlling of anthracnose disease, appropriately.

The first report of anthracnose disease management in mango was by Jeffries et al. (1990), in which fungicide application was suggested for the management of this disease due to its ease of use and success in disease control (Cools et al. 2005). Carbendazim, a member of the benzimidazole class, is a fungicide that is widely used for anthracnose disease control and can be managed both in the field and postharvest. The mode of action of carbendazim is the inhibition of mitosis and cell division ( $\beta$-tubulin assembly in mitosis), but recently, the appearance of fungal resistance has become important and has affected the ability to use the fungicide for anthracnose management in the mango industry (Brent 1995). The report of the Fungicide Resistance Action Committee (FRAC) (2020) explained that fungicides have become an integral part of efficient food production and that the loss of a fungicide through resistance is a problem that affects everyone.

The methods for fungicide resistance detection require isolation of pathogens treated with each fungicide (Anon 1991), but these processes are time-consuming. Currently, molecular biology is a new method for fungicide detection once the other mechanisms have been exhausted. For carbendazim, Ma and Michailides (2005) reviewed the molecular mechanisms of fungicide resistance in four fungicide classes, including the benzimidazole class. The results indicated that resistance was correlated with point mutations in the $\beta$-tubulin gene, resulting in altered amino acid sequences at the benzimidazole site, and most of the results from numerous studies have shown that changes at codons 198, 200 and 240 in the $\beta$-tubulin gene could cause benzimidazole resistance (Ma et al. 2003; Nalumpang et al. 2010; Peres et al. 2004).

Apart from this, RFLP markers are codominant and highly locus-specific because of the restriction site and cutting site of each restriction enzyme (National Center for Biotechnology Information 2017). For example, N Ziogas et al. (2009) studied gray mold disease of strawberry in Greece and examined the sensitivity to benzimidazoles (carbendazim and diethofencarb) by using a set of PCR-specific primers designed to amplify a portion of $\beta$-tubulin and digestion with $B s a I$. The results of these studies showed that the differentiation between sensitive and resistant 
strains based on digested products could be detected via; PCR-RFLP of benomyl resistant strains of Mycosphaerella fijiensis in Colombia (Cañas-Gutiérrez et al. 2006), and many reports applied this method to detect other fungicide resistance of plant pathogenic fungi within a short time (Cunha and Rizzo 2003; Ishii et al. 2002; Ma et al. 2003)

Although the RFLP technique is a simple method and the markers are codominant for the detection of point mutations, some target fragments may not contain a restriction endonuclease recognition sequence at the site of point mutation. However, preliminary restriction enzyme cutting analysis has become a useful method to create and simulate RFLP patterns. A virtual RFLP assay was developed for classifying over 800 publicly available Phytoplasma 16S rRNA gene sequences, and the results showed that computer-simulated RFLP was highly effective in classifying and separating the 28 groups with the highest similarity coefficients (Wei et al. 2007). Hence, the rapid detection method was applied as an essential tool for fungicide resistance inspection to improve fungicide utilization for anthracnose control. The aim of this research was to detect carbendazim resistance in anthracnose disease in the mango cv. Nam Dork Mai See Tong using molecular characterization and a modified PCR-RFLP as a rapid technique.

\section{Materials and Methods}

\section{Fungal isolation}

Thirty-two isolates of Colletotrichum species were obtained from mango fruits with typical anthracnose symptoms in 3 mango plantation provinces of Thailand, Chachoengsao, Phichit and Ratchaburi, in 2016 - 2017 and cultured using a tissue transplanting technique on potato dextrose agar (PDA). Later, mycelial cutting was performed by placement on fresh PDA, and samples were incubated at $25^{\circ} \mathrm{C}$ under a photoperiod of $12 \mathrm{hr}$ light / $12 \mathrm{hr}$ dark for 5 days. Then, mycelia were transferred onto potato carrot agar (PCA), and finally, the cultures were kept at $14^{\circ} \mathrm{C}$ for further study.

\section{Morphological identification}

Petri dished containing $15 \mathrm{~mL}$ of PDA were inoculated with a $5 \mathrm{~mm}$ in diameter core taken from the edge of an activity growing 5-day old culture. The culture was incubated at $25^{\circ} \mathrm{C}$ under a photoperiod of $12 \mathrm{hr}$ light/12 hr dark. Colony type and spore mass color were recorded at day 5. Fifty conidia were randomly selected from each replicate to measure their length and width under compound microscope with Olympus CellSens Standard software version 1.6. Appressoria were induced with modified slide culture technique (Johnston and Jones, 1997). The isolates 5-day old cultures on PDA were transferred onto $25.4 \times 76.2 \mathrm{~mm}$ sterile microscope slides and covered with $22 \times 22 \mathrm{~mm}$ cover slips incubated in petri dish to serve as a moisture chamber under $25^{\circ} \mathrm{C}$ for 4 days. Length and width of 30 appressoria per isolate were measured under compound microscope with Olympus CellSens Standard software version 1.6.

\section{DNA extraction and fungal confirmation}

Genomic DNA of each isolate was extracted using the method of Pongpisutta et al. (2013) and the modified protocol of Zimand et al. (1994). PCR amplification was performed for the partial internal transcribed spacer (ITS region), actin gene (ACT), chitin synthase 1 gene (CHS-1) and $\beta$-tubulin (TUB) regions, as well as with specific primers for $C$. acutatum and $C$. gloeosporioides (Table 1). The PCR master mix had a total volume of $25 \mu \mathrm{L}$. The PCR mixture contained $2 \mu \mathrm{L}$ of $20 \mathrm{ng}$ genomic DNA, $0.48 \mu \mathrm{M}$ of each primer, 0.69X Taq buffer (Thermo Fisher 
Scientific, Massachusetts, USA), $2.4 \mathrm{mM} \mathrm{MgCl} 2,10 \mu \mathrm{M}$ of each dNTP, $1 \mathrm{U}$ Taq polymerase (Thermo Fisher Scientific, Massachusetts, USA) and $14.4 \mu \mathrm{L}$ of sterile distilled water.

PCR thermal cycling (Sensoquest GmbH, Göttingen, Germany) was carried out using the following program: predenaturation at $94^{\circ} \mathrm{C}$ for $2 \mathrm{~min}, 35$ cycles of denaturation at $94^{\circ} \mathrm{C}$ for $30 \mathrm{~s}$, annealing for $30 \mathrm{~s}$ (the temperature each of primer is shown in Table 1) and extension at $72^{\circ} \mathrm{C}$ for $1 \mathrm{~min}$, with a final extension step of $72^{\circ} \mathrm{C}$ for 10 min. PCR products were stained with GelStar ${ }^{\circledR}$ and verified on $1.2 \%$ agarose gels via electrophoresis in $1 \mathrm{X}$ TBE buffer at a constant power of 80 volts with the GeneRuler 100 bp Plus DNA Ladder (Thermo Fisher Scientific, Massachusetts, USA) used for comparison. The gels were photographed under UV radiation with a $365 \mathrm{~nm}$ wavelength using a GeneFlash Gel Documentation System (Syngene, Cambridge, UK). Sequencing of the PCR products was performed by 1st Base Laboratory Co., Ltd. in Malaysia. Consensus sequences were produced using the EditSeq program of the sequence analysis software (DNAStar Inc., WI, USA) by careful trimming and editing and then compared by Basic BLASTn (https://blast.ncbi.nlm.nih.gov/Blast.cgi) to the GenBank National Center for Biotechnology Information (NCBI) database.

\section{Phylogenetic analyses}

Analysis of the sequence data was performed by the MEGA version X software program (Kumar et al. 2018) for phylogenetic tree confirmation. A comparison of the sequences of 4 loci (ACT, CHS-1, ITS, TUB) was carried out by choosing Colletotrichum species from the Genbank database. Data alignments were achieved by using the clustalW alignment routine (Thompson et al. 1994). The phylogenetic tree was generated using the maximum likelihood (Tamura et al. 2011), and the confidence of the groupings was determined by bootstrap analysis (Felsenstein 1985), which was performed using 1,000 replications to test the significance the trees.

\section{Pathogenicity test}

Representative isolate of Colletotrichum species complex were used for pathogenicity test on immature mango fruits and third branch leaves from 6-month seedling (cv. Nam Dork Mai See Tong) under laboratory conditions. All isolates were cultured on PDA and incubated at $25^{\circ} \mathrm{C}$ under a photoperiod of $12 \mathrm{hr}$ light $/ 12 \mathrm{hr}$ dark for 5 days, then cut the colony margin with cork borer and transferred $5 \mathrm{~mm}$ mycelial plug onto mango fruits and leaves which washed with $1.2 \%$ sodium hypochlorite for $1 \mathrm{~min}$ and sterile distilled water. Inoculated fruits and leaves were used unwounded technique, then kept in moisture box and incubated at room temperature in the photoperiod of $12 \mathrm{hr}$ light / $12 \mathrm{hr}$ dark for 5 days symptom developing.

\section{Carbendazim resistibility assays}

The minimum inhibitory concentration (MIC) was used to determine fungal resistibility. Colletotrichum isolates were grown on PDA incubated at $25^{\circ} \mathrm{C}$ under a photoperiod of $12 \mathrm{hr}$ light $/ 12 \mathrm{hr}$ dark for 5 days. Then, $5 \mathrm{~mm}$ mycelial plugs were cut from the colony margin with cork borer and transferred to a 24-well cell culture cluster of PDA augmented with carbendazim at concentrations of $0.1,1,10,100$, and $1,000 \mu \mathrm{g} / \mathrm{mL}$ and the recommended rate in the field $(500 \mu \mathrm{g} / \mathrm{mL})$; all samples were incubated under the same conditions. Four levels of evaluation were examined as described in Table 2.

\section{Partial sequencing of the $\beta$-tubulin gene and sequence alignment}

Primers TB2L (5' GYTTCCAGATYACCCACTCC ‘3) and TB2R (5' -TGAGCTCAGGAACRCTGA CG ‘3) (Peres et al. 2004) were used to amplify a portion of the $\beta$-tubulin gene for the detection of point mutations associated with resistance. The PCR master mix had a total volume of $25 \mu \mathrm{L}$. The PCR mixture contained $2 \mu \mathrm{L}$ of $20 \mathrm{ng}$ genomic DNA, $0.48 \mu \mathrm{M}$ of each primer, 0.69X Taq buffer (Thermo Fisher Scientific, Massachusetts, 
USA), $2.4 \mathrm{mM} \mathrm{MgCl} 2,10 \mu \mathrm{M}$ of each dNTP, $1 \mathrm{U}$ Taq polymerase (Thermo Fisher Scientific, Massachusetts, USA) and $14.4 \mu \mathrm{L}$ of sterile distilled water. PCR was carried out in a programmable thermal cycle as follows: pre-denaturation at $94^{\circ} \mathrm{C}$ for $5 \mathrm{~min} ; 30$ cycles of denaturation at $94^{\circ} \mathrm{C}$ for $1 \mathrm{~min}$, annealing at $35^{\circ} \mathrm{C}$ for $1 \mathrm{~min}$ and extension at $72^{\circ} \mathrm{C}$ for $1 \mathrm{~min}$; and a final extension step of $72^{\circ} \mathrm{C}$ for $5 \mathrm{~min}$. PCR products were stained with GelStar and separated by electrophoresis on a $1.2 \%$ agarose gel in $1 \mathrm{X}$ TBE buffer at 80 volts. The gels were recorded under UV radiation with a $365 \mathrm{~nm}$ wavelength using the GeneFlash Gel Documentation System. PCR product sequencing was performed at 1st Base Laboratory Co., Ltd. in Malaysia.

Nucleotide sequences were translated into amino acid sequences using Expasy by the SIB Swiss Institute of Bioinformatics (https://web.expasy.org/translate/) and The Sequence Manipulation Suite (https://www.bio informatics.org/sms/show trans.html). The data were aligned using EMBL-EBI clustal omega (https://www .ebi.ac.uk/Tools/msa/clustalo/) and edited by MEGA version X software. Protein homology modeling was applied using CPH model version 3.2 (http://www.cbs.dtu.dk/services/CPHmodels/) in PDB mode, and molecular graphics visualization was performed using RasMol Molecular Graphics version 2.7.5.2 for Windows to study protein structure differentiation between sensitive and resistant strains to carbendazim fungicides.

\section{RFLP analysis}

Computer-simulated RFLP analysis of the sequences was conducted. Before the experiment, all nucleotide sequences were edited using MEGA version $X$ software (Kumar et al. 2018) to ensure that the start and end points of all samples were the same. Over 86 restriction enzymes were screened for in silico restriction digestion using pDRAW32 DNA analysis software (AcaClone Software, https://www.acaclone.com/). After digestion, 2.0\% agarose gel electrophoresis was performed by comparison with the Fermentas 100 bp Plus DNA Ladder. Digested products were generated by adding the restriction enzymes according to the manufacturer's instructions, and the banding pat-terns of the products were determined. Each digestion reaction had a final volume of $30 \mu \mathrm{l}$ and contained $17 \mu \mathrm{l}$ of nuclease-free water, $2 \mu 1$ of 10X FastDigest Green Buffer, $10 \mu \mathrm{l}(\sim 0.2 \mu \mathrm{g})$ of PCR product and $1 \mu 1$ of FastDigest enzyme. Samples were mixed gently and incubated at $37^{\circ} \mathrm{C}$ in a heat block for $5 \mathrm{~min}$. The digested products were stained with GelStar ${ }^{\circledR}$ and separated by $2.0 \%$ agarose gel electrophoresis in $1 \mathrm{X}$ TBE buffer at 80 volts; gels were observed under $365 \mathrm{~nm}$ wavelength UV radiation via the GeneFlash Gel Documentation System.

\section{Results}

\section{Fungal isolation and identification}

During disease survey, anthracnose symptoms in the mango orchards were observed (Table S1). On mango, disease symptoms of anthracnose were separated into 3 types: 1) $6.25 \%$ of the symptom on inflorescences are dark-brown spots to elongated dark lesions which can enlarge, coalesce, and blighted flowers affecting small emerging fruits that could fall out, then (Fig. 1a-1b), 2) $21.87 \%$ of lesions on leaves start as brown to black small spot, then developing to irregularly shaped lesions with brown-gray to black necrotic spots on leaf surfaces (Fig. 1c-1d), and 3) 71.88\% small black circular spots becoming sunken, rounded brown to black lesions on ripe fruits and producing acervuli on the lesions with bright salmon, salmon-orange to pale colored spore masses at high relative humidity. Premature fruits can be dropped from the trees. Furthermore, the spot decay on mature-fruit during harvesting or transportation can penetrate deep into the fruit, resulting in extensive fruit rotting (Fig. 1e1f). Morphological markers of 32 isolates from Sutton (1980) were identified as only belonging to the $C$. 
238

239

240

241

242

243

244

245

246

247

248

249

250

251

252

253

254

255

256

257

258

259

260

261

262

263

264

265

266

267

268

269

270

271

272

273

274

275

276

277

gloeosporioides species complex due to their cottony aerial mycelia and white to gray mycelia covered with pale to orange spore masses (Fig. 2a-2j). Conidia were straight to cylindrical with round ends $((3.59) 6.91 \times$ 11.02(19.52) $\mu \mathrm{m})($ Fig. 2k-2t), no setae, and appressoria pale to dark brown with various shapes such as clavate, long clavate to irregular $((4.37) 7.31 \times 6.49(11.59) \mu \mathrm{m})($ Table S2; Fig. 2u-2ad; Fig. S1). Then, identification of species complexes using PCR techniques based on multilocus phylogenetic analyses was performed.

\section{Phylogenetic analyses}

Total genomic DNA was used as the template for identification using PCR. Molecular detection with the speciesspecific primers CaInt/ITS4 and CgInt/ITS4 was utilized to detect the Colletotrichum samples in this study. The species-specific primers $C g$ Int/ITS4 amplified an approximately 500 bp fragment from all isolates, while CaInt/ITS4 did not amplify this fragment. Blast comparison showed that ten isolates were identified as C. asianum with $96.62-100.00 \%$, three isolates were determined to be C. gloeosporioides with $86.00-100.00 \%$, while three isolates (RB003, RB006 and PC002) were accurately classified as C. siamense with 96.00- 100.00\%.

Phylogenetic analysis of multiple loci (ACT gene, CHS-1 gene, ITS region and TUB gene) used ClustalW as implemented in MEGA version X (Kumar et al. 2018), and manually adjusted to allow high sequence similarity. Additionally, the same software was used to carry out the statistical selection of best-fit models of nucleotide substitution, the result showed that all nucleotide sequence alignments of genes were conducted using a maximum likelihood (ML) method supported by the Kimura 2-parameter model combined with gamma distribution $(G)$ (Archibald et al. 2003) and compared with the ex-holotype/epi-type in Table 3. Ten isolates were absolutely identified as $C$. asianum with $95 \%$ bootstrap values. Furthermore, three representative isolates were determined to be $C$. gloeosporioides with approximately bootstrap value $86 \%$, while two representative isolates (RB003, RB006 and PC002) were accurately classified as C. siamense with high bootstrap values $96 \%$ shown in the branch of phylogenetic tree (Fig. 3). All the sequences (excepted results of specific-primer) generated in this study were deposited in GenBank and DDBJ for assigning accession numbers (Table 3).

\section{Pathogenicity test}

Colletotrichum isolates RB005, CS008 and RB003 were selected from C. asianum, C. gloeosporioides and C. siamense, respectively, in order to test their pathogenicity. Symptom on unwounded fruits and leaves developed sunken spot, dark brown to brown lesion at day 5 after inoculation (Fig. 4). The damage of Colletotrichum gloeosporioides had the highest infection incidence reached to $100 \%$ in both inoculated fruits and leaves, while the $C$. asianum and C. siamense were about 75 and $60 \%$ on fruits and each absolutely counting $100 \%$ on leaves (Table 4).

\section{Carbendazim resistibility assays}

Thirty-two isolates of Colletotrichum separated into 3 species were tested for carbendazim responsiveness by MIC assay on PDA amended with carbendazim at concentrations of $0.1-1,000 \mathrm{mg} / \mathrm{L}$, including the recommended rate. The results indicated that 9 isolates $(90.00 \%)$ of $C$. asianum were found to be HR strains, while one isolate $(10.00 \%)$ was found to be an R strain. Six isolates (31.58\%) of C. gloeosporioides were clustered as sensitive strains, and 5 isolates $(26.32 \%)$ were proven to be R strains; moreover, 8 isolates $(42.11 \%)$ were revealed to be HR strains. Ultimately, all 3 isolates $(100.00 \%)$ of $C$. siamense were evaluated to be HR strains (Table 5). 
PCR products (approximately $450 \mathrm{bp}$ ) of the partial $\beta$-tubulin sequence from all 32 isolates were generated with TB2L/TB2R primers and electrophoresed on a 1.2\% agarose gel (Fig. $5 \mathrm{c}$ ). The $\mathrm{S}$ strains showed the nucleotides GAG (glutamic acid; Glu (E)) at codon 198 and TTC (phenylalanine; Phe (F)) at codon 200, while the HR strains showed the nucleotides GCG (alanine; Ala (A)) at codon 198. The R strains had a point mutation at codon 200, resulting in the nucleotides TAC (tyrosine; Tyr (Y)) (Fig. 5a 5b, 5f). Other point mutation within the remaining codons, such as codons 167 and 240, were studied with the same pair of primers, and no differentiation was detected. The results indicated that the mutated codons E198A and F200Y of the $\beta$-tubulin gene were related to the responsiveness phenotype of the 3 Colletotrichum species causing mango anthracnose and were associated with resistance to $\mathrm{MBC}$ fungicides, such as carbendazim, in this study.

\section{RFLP analysis}

The partial $\beta$-tubulin gene sequence amplified with the TB2L/TB2R primers was subjected to in silico RFLP using pDRAW32 software to assess HR, R and S strains. The results showed that 37 of 86 restriction enzymes in the program did not cut the PCR fragment. However, the Bst UI restriction enzyme revealed distinctly different fragments among the 3 strains (Fig. 6c, 6d). Digestion of the HR strain with Bsh1236I (isoschizomers: AccII, $B s p$ FNI, BstFNI, Bst $\mathrm{UI}, M v n \mathrm{I}$ ) generated bands of approximately 200 and $300 \mathrm{bp}$, while the $\mathrm{S}$ strain and R strain products were not cut (Fig. 6b, 6e). The Bsh $1236 \mathrm{I}$ enzyme recognizes the $\mathrm{CG}^{\wedge} \mathrm{CG}$ site and cuts at the position of codon 198, which was useful for distinguishing between HR and S strains. For the R strain, the HpyAV restriction enzyme (isoschizomers: Hin4II) cut and showed differentiation between R and HR or S strains, but the cut and recognition sites were not positioned at codon 200 (Fig. 6). Hence, RFLP using the Bsh1236I restriction enzyme was a useful and rapid technique for preliminary detection of strains highly resistant to carbendazim. Thus, the PCR-RFLP technique can be used to assess the fungicide resistance of Colletotrichum causing mango anthracnose disease.

\section{Discussion}

302 In Thailand, most reports in the past have described and identified fungi causing anthracnose disease of mango in plantation areas as Colletotrichum gloeosporioides. Nonetheless, there is a report in the years 2010 showed that C. gloeosporioides was actually not a common pathogen in the tropics and it was not the main causal pathogen of mango anthracnose in Laos and Thailand, in spite of first understanding that anthracnose of most tropical fruits is caused by $C$. gloeosporioides but molecular analysis, showed that most of the fungal samples still belong into the "C. gloeosporioides species complex" (Phoulivong et al. 2010). So far as anyone know, molecular classification based on ITS sequences was typically used for identified anthracnose-pathogens including other fungi. Recently; it was found that ITS-region were unable to distinctly resolve the species identification of individual Colletotrichum. The information of Wei et al. (2012) reported that ITS sequences are insufficient to separate $C$. aenigma, $C$. aeschynomenes, $C$. alienum and some $C$. siamense isolates. These taxa are best differentiated by using TUB, gluta-mine synthetase (GS) or manganese-superoxide dismutase (SOD2). For $C$. asianum or $C$. gloeosporioides are distinguished from all other taxa using any of the genes tested, excluding ITS.

314 However, this study investigated Colletotrichum 32 isolates obtained from 3 important mango plantation areas based on morphological characteristics and pathogenicity tests performance combined with multiloci molecular phylogenetic analysis, the fungal pathogens were clearly divided into 3 species: C. asianum, C. gloeosporioides 
fruits and leaves. The typically symptom of each species infected mango shown similar, there are depressed black lesion which are sub circular and in which spore mass develop with high humidity (Bailey and Jeger. 1992). The pathogenicity assay indicated that 3 species were causal agents on mango anthracnose disease, Some Thai researchers have previously reported that $C$. gloeosporioides is mainly causal agent of mango and chilli anthracnose while $C$. asianum and $C$. siamense are also cause coffee berry disease (Đinh et al. 2003; Đinh and Sangchote 2002; Prihastuti et al. 2009; Rungjindamai. 2016; Sangchote. 2013; Than et al. 2008). Other from this, in Brazil, China or India, important mango producer, have reported Colletotrichum species more than 5 species; C. cliviicola, C. cordylinicola, C. endophytica, C. fructicola, C. karstii, C. tropicale etc. can be pathogenic to mango (Li et al., 2019; Lima et al. 2013; Mo et al. 2018; Zakaria. 2021). Our results showed that the most common fungal isolates related to mango involved 3 species: $C$. asianum, C. gloeosporioides and $C$. siamense. Only $C$. gloeosporioides have previously been reported on mango, while $C$. asianum and $C$. siamense were first reports associated with mango in Thailand.

Anthracnose control and fungicide application are crucial for treating plants and producing high-quality agricultural products. Most report addressing several new products have been introduced, including single-site and combination fungicides classes for profitable against anthracnose fungal pathogens and also effective disease control (Tredway and Wong. 2012). Carbendazim, a member of the benzimidazole group of fungicides, is a major fungicide used to control mango anthracnose and has been reported by many researchers (Kim et al. 2007, 2020; Nagaraju et al. 2019). Although carbendazim is a fungicide affecting mango anthracnose control, the appearance of fungicide resistance is currently becoming a factor limiting the potential of this drug (Ma and Michailides. 2005).

The mode of action (MOA) of carbendazim, a member of the benzimidazole group of fungicides, is associated with interference in the biosynthesis of DNA during fungal cell division, biosynthesis of the $\beta$-tubulin gene and the polymerization of $\beta 2$-tubulin, which is the main mechanism of action of benzimidazole compounds, such as benomyl and thiophanate-methyl fungicides (Qiu et al. 2011; Zhou et al. 2016). Several mutations in the $\beta$-tubulin gene can lead to benzimidazole fungicide resistance.

The codon changes in most field-resistant isolates that have arisen for several fungal plant pathogens seem to be restricted to positions 6, 50, 167, 198, 200 and 240 (Zhan et al. 2014). For mutation or resistance detection, several studies, including this research, have detected mutations in the $\beta$-tubulin gene at codon 198, which resulted in a substitution of glutamic acid (GAG) in the S strain to alanine (GCG) in the R strain (Nalumpang et al. 2010; Peres et al. 2004). This mutation is present not only in the genus Colletotrichum but also in other plant pathogens, such as Botrytis cinerea, Penicillium aurantiogriseum and Helminthosporium solani (Cunha and Rizzo 2003; Koenraadt et al. 1992; Luck and Gillings. 1995). Some reports have also found different affected codons in some plant pathogenic fungi, such as codon 6 in Monilinia fructicola, a substitution resulting in a change of histidine to tyrosine at codon 200 in C. gloeosporioides isolated from tropical fruit in Taiwan, and a nucleotide substitution resulting in a change of phenylalanine to tyrosine (Chung et al. 2010).

In this study, we found C. asianum isolates (10 isolates) showing HR (9 isolates) and R (1 isolate) to carbendazim, and all the isolates (3 isolates) of C. siamense showed HR. However, only C. gloeosporioides isolates (6 isolates) were sensitive to carbendazim. The results as mentioned in Table 5, most of Colletotrichum, isolated from mango cv. Nam Dork Mai See Tong showed highly resistance to carbendazim fungicide to $62.5 \%$ (20 isolates) of the fungal samples. The MIC values showed more than 1,000 ppm for highly resistance strains of three Colletotrichum 
species which was exceeding the recommended rate of carbendazim (approximately $500 \mathrm{ppm} ; 20 \mathrm{cc} / 20 \mathrm{~L}$ with active ingredient $50 \mathrm{w} / \mathrm{v}$ in suspension concentrate type). Although, other researchers have informed development of carbendazim or fungicide in class benzimidazole from several areas or host plants including various mango cultivars in Thailand (Nalumpang et al. 2010; Poti et al. 2020); but this is the first report of technique for carbendazim-resistant detection in mango cv. Nam Dork Mai See Tong that caused by Colletotrichum 3 species. Usually, fungicide resistance studies require isolation of the pathogen in a pure culture and subsequent plating on a medium containing fungicide or a "poisoned food" (Anon 1982, 1991). The conventional method is timeconsuming, which is why molecular techniques provide a new opportunity for rapid detection. Although molecular tools are rapid techniques, most studies differentiate between $\mathrm{S}$ and $\mathrm{R}$ strains by using nucleotide sequencing analysis as showed in Fig. 5a and 5b.

However, the fungicide detection method is expensive. Hence, polymerase chain reaction-restriction fragment length polymorphism (PCR-RFLP) has been used to detect fungicide resistance. In this research, we indicated that these techniques are highly specific and prompt for detecting fungicide responsiveness. Rosenzweig et al. (2015) developed PCR-RFLP to detect the G143A and E198A point mutations of the cytochrome $b$ and $\beta$-tubulin genes in Cercospora leaf spot (CLS) caused by Cercospora beticola in Michigan sugar beet (Beta vulgaris) fields. The results showed that the PCR-RFLP assay was effective in detecting the presence of the G143A and E198A mutations in C. beticola from field populations in Michigan. For this research, restriction enzyme Bsh1236I can use to digest PCR products of the Colletotrichum HR strains, excellently. Whilst in R strain had a point mutation at codon 200, the result revealed that some restriction enzymes appeared in silico can cut product but the cut and recognition sites were not positioned at target codon. So, a modification of PCR-RFLP assay must be developed as the report of Chung et al. (2010), which study benzimidazole-resistant with designed specific primers for scope the codon or utilized wild-type strain (N Ziogas et al. 2009). Moreover, PCR-RFLP is a rapid technique for fungicide resistance detection in the case of carbendazim and azoxystrobin (Cañas-Gutiérrez et al. 2006; Chung et al. 2010; Inada et al. 2008), but some microorganisms, especially the genus Colletotrichum, are highly variable phenotypic diversity within taxa/species complex and may not contain a recognition site sequence at the site of point mutation. Therefore, virtual RFLP analysis (in silico) is a convenient method for preliminary potential digestion of each restriction enzyme as a reliable alternative to conventional PCR-RFLP, as shown in Fig. 5d and Fig. 6.

Furthermore, RFLP or virtual RFLP techniques are considered to be essential tools to solve the problems of species differentiation in microorganisms, such as the identification of 3 species of Colletotrichum causing chili anthracnose in Thailand, pineapple spoilage fungi, and three major Meloidogyne species in Korea, as well as the classification of phytoplasma using cpn60 universal target sequences (Han et al. 2004; Koffi et al. 2019; PérezLópez et al. 2016; Pongpisutta et al. 2013) Apart from this, In silico testing has reported that this method can be solve the error of PCR-RFLP method, caused by primers that may not amplify PCR products and low PCR product concentration that affect availability of template for cleavage by restriction enzymes and affect visibility of digested product on agarose gels, including PCR master mixed such as $\mathrm{MgCl}_{2}$, Taq buffer contained with $\mathrm{KCl}$ or $\left(\mathrm{NH}_{4}\right)_{2} \mathrm{SO}_{4}$ and primer dimers that can inhibit activity of restriction enzyme (Ramdeen and Rampersad 2014). This research is not only identification but also differentiation among sensitive, resistant and highly resistant strains in population of Colletotrichum species obtained from mango anthracnose disease by using virtual PCRRFLP and confirm with PCR-RFLP in gel electrophoresis. The method can be performed in a very short time and 
398

399

400

401

402

403

404

405

406

407

408

409

410

411

412

413

414

415

416

417

418

419

420

421

422

423

424

425

426

427

428

429

430

431

432

433

434

435

436

achieved reliable data comparing to the old assay such as poisoned food or $\mathrm{ED}_{50}$ calculation, then PCR-RFLP technique illustrated the potential to specifically detect benzimidazole fungicide resistance in 3 species of Colletotrichum like C. asianum, C. gloeosporioides and C. siamense. Furthermore, this technique is accessible and feasible for laboratory assessment. It is a crucial caution and signal for precise management using fungicide utilization with the target to achieve effective control. Once, the mutation fungal strains invade in a field, it is quite tough to reduce the population of these strains. Hence, a rotation of different fungicide groups is needed. Moreover, this is the first report of carbendazim resistance of three species of Colletotrichum, causal agents of mango anthracnose in Thailand using PCR-RFLP for benzimidazole fungicide resistant detection.

\section{Acknowledgments:}

We would also like to thank the Mycology Laboratory and Physiology of Plant Disease Laboratory, Department of Plant Pathology, Faculty of Agriculture at Kamphaeng Saen, Kasetsart University, Kamphaeng Saen Campus, Nakhon Pathom, Thailand for their laboratory equipment in plant pathology support.

\section{Declarations:}

Funding: This research was funded by the Postharvest Technology Innovation Center, Ministry of Higher Education, Science, Research and Innovation, Bangkok, Thailand. [Grant No. CRP.3. NOV11.8].

Conflicts of interest/Competing interests: The authors declare no conflict of interest.

Code availability: Not applicable.

Authors' contributions: R.P. and C.R. Conceptualization; S.B., R.P and C.R. methodology, software, formal analysis, writing—original draft preparation; R.P. and C.R. supervision project administration, funding acquisition; S.B., R.P. and C.R. investigation, data curation; R.P. and C.R. validation, resource, writing-review and editing. All authors have read and agreed to the published version of the manuscript.

Ethics approval: Not applicable.

\section{References:}

Anon (1982) Recommended methods for the detection and measurement of resistance of agricultural pests to pesticides. FAO Plant Prot Bull 30: 36-143.

Anon (1991) FRAC methods for monitoring fungicide resistance. Bull OEPP 21: 291-354.

Archibald JK, Mort ME, Crawford DJ (2003) Bayesian inference of phylogeny: a non-technical primer. Taxon 52: 187-191. https://doi.org/10.2307/3647388

Bailey JA, Jeger MJ (1992) Colletotrichum: biology, pathology and control. Wallingford, UK

Brent KJ (1995) Fungicide resistance in crop pathogens: How can it be managed?. GIFAP, Brussels: FRAC Monograph No 1.

Buhr TL, Dickman MB (1993) Isolation and characterization of a $\beta$-tubulin-encoding gene from Colletotrichum gloeosporioides f. sp. aeschynomene. Gene 124: 121-125. https://doi.org/10.1016/0378-1119(93)90771-T

Cañas-Gutiérrez GP, Patiño LF, Rodríguez-Arango E, Arango R (2006) Molecular characterization of benomylresistant isolates of Mycosphaerella fijiensis, collected in Colombia. J Phytopathol 154: 403-409.

https://doi.org/10.1111/j.1439-0434.2006.01113.x 
Carbone I, Kohn LM (1999) A method for designing primer sets for speciation studies in filamentous ascomycetes. Mycologia 91:553-556. https://doi.org/10.2307/3761358

Chung W-H, Chung W-C, Peng M-T, Yang H-R., Huang J-W (2010) Specific detection of benzimidazole resistance in Colletotrichum gloeosporioides from fruit crops by PCR-RFLP. New Biotechnol 27: 17-24. https://doi.org/10.1016/j.nbt.2009.10.004

Cools HJ, Fraaije B, Lucas JA (2005) Molecular examination of Septoria tritici isolates with reduced sensitivity to triazoles. Paper presented at the $14^{\text {th }}$ International Reinhardsbrunn Symposium; Modern Fungicides and Antifungal Compounds, Friedrichroda, Germany.

Cunha MG, Rizzo DM (2003) Development of fungicide cross resistance in Helminthosporium solani populations from California. Plant Dis 87: 798-803. https://doi.org/10.1094/PDIS.2003.87.7.798

Damm U, Cannon PF, Woudenberg JH, Crous PW (2012a) The Colletotrichum acutatum species complex. Stud Mycol 73: 37-113. https://doi.org/10.3114/sim0010

Damm U, Cannon PF, Woudenberg JH, et al. (2012b) The Colletotrichum boninense species complex. Stud Mycol 73: 1-36. https://doi.org/10.3114/sim0002

Đinh Q, Chongwungse J, Pongam P, Sangchote S (2003) Fruit infection by Colletotrichum gloeosporioides and anthracnose resistance of some mango cultivars in Thailand. Australas Plant Pathol 32: 533-538. https://doi.org/10.1071/AP03053

Đinh Q, Sangchote S (2002) Infection of Colletotrichum gloeosporioides on mango fruit and its resistance. J Agric Sci 33(Suppl.): 68-70.

Felsenstein J (1985) Confidence limits on phylogenies: an approach using the bootstrap. Evol 39: 783-791. https://doi.org/10.2307/2408678

Fungicide resistance action committee (FRAC) (2020) FRAC Code List $\odot * 2020$ : Fungal control agents sorted by cross resistance pattern and mode of action (including FRAC Code numbering). https://cpb-usw2.wpmucdn.com/u.osu.edu/dist/b/28945/files/2020/02/frac-code-list-2020-final.pdf. Accessed 3 January 2020

Han H, Cho M, Jeon H, Lim C, Jang H (2004) PCR-RFLP identification of three major Meloidogyne species in Korea. J Asia Pac Entomol 7: 171-175. https://doi.org/10.1016/S1226-8615(08)60212-5

Inada M, Ishii H, Chung W, Yamada T, Yamaguchi J, Furuta A (2008) Occurrence of strobilurin-resistant strains of Colletotrichum gloeosporioides (Glomerella cingulata), the causal fungus of strawberry anthracnose. Japanese Journal of Phytopathology 74: 114-117. https://doi.org/10.3186/jjphytopath .74.114

Ishii H, Fraaije B, Sugiyama T, Noguchi K, Nishimura K, et al. (2002) Occurrence and molecular characterization of strobilurin resistance in cucumber powdery mildew and downy mildew. Phytopathology 91: 1166-1171. https://doi.org/10.1094/PHYTO.2001.91.12.1166

Jeffries P, Dodd JC, Jeger MJ, Plumbley RA (1990) The biology and control of Colletotrichum species on tropical fruit crops. Plant Pathol 39: 343-366. https://doi.org/10.1111/j.1365-3059.1990.tb02512.x

Johnston P, Jones D (1997) Relationships among Colletotrichum isolates from fruit-rots assessed using rDNA sequences. Mycologia 89: 420-430. https://doi.org/10.1080/00275514.1997.12026801

Kim CH, Hassan O, Chang T (2020) Diversity, pathogenicity, and fungicide sensitivity of Colletotrichum species associated with apple anthracnose in South Korea. Plant Dis 104: 2866-2874. https://doi.org/10.10 94/PDIS-01-20-0050-RE 
Kim Y-S, Min JY, Kang BK, Bach NV, Choi WB, Park EW, Kim HT (2007) Analyses of the less benzimidazole-sensitivity of the isolates of Colletotrichum spp. causing the anthracnose in pepper and strawberry. Plant Pathol J 23: 187-192. https://doi.org/10.5423/PPJ.2007.23.3.187

Koenraadt H, Somerville SC, Jones AL (1992) Characterization of mutations in the $\beta$-tubulin gene of benomylresistant field strains of Venturia inaequalis and other plant pathogenic fungi. Phytopathology 82: 13481354.

Koffi Y, Diguta C, Alloue-Boraud M, Koffi L, Dje M, Gherghina E, (Radoi) Matei F (2019) PCR-ITS-RFLP identification of pineapple spoilage fungi. Rom Biotechnol Lett 24: 418-424. https://doi.org/10.250 $\underline{83 / \mathrm{rbl} / 24.3 / 418.424}$

Kumar S, Stecher G, Li M, Knyaz C, Tamura K (2018) MEGA X: Molecular evolutionary genetics analysis across computing platforms. Mol Biol Evol 35: 1547-1549. https://doi.org/10.1093/molbev/msy096

Li Q, Bu J, Shu J, Yu Z, Tang L, Huang S et al. (2019) Colletotrichum species associated with mango in southern China. Sci Rep 9: 18891. https://doi.org/10.1038/s41598-019-54809-4

Lima NB, de A Batista MV, de Morais MA, Barbosa MAG, Michereff SJ, Hyde KD, Câmara MPS (2013) Five Colletotrichum species are responsible for mango anthracnose in northeastern Brazil. Fungal Divers 61: 75 88. https://doi.org/10.1007/s13225-013-0237-6

Luck JE, Gillings MR (1995) Rapid identification of benomyl resistant strains of Botrytis cinerea using the polymerase chain reaction. Mycol Res 99: 1483-1488. https://doi.org/10.1016/S0953-7562(09)80797-1

Ma Z, Michailides T (2005) Advances in understanding molecular mechanisms of fungicide resistance and molecular detection of resistant genotypes in phytopathogenic fungi. Crop Prot 24: 853-863. https://doi.org/10.1016/j.cropro.2005.01.011

Ma Z, Yoshimura M, Michailides TJ (2003) Identification and characterization of benzimidazole resistance in Monilinia fructicola from stone fruit orchards in California. Appl Environ Microbiol 69: 7145-7152. https://doi.org/10.1128/AEM.69.12.7145-7152.2003

Mills PR, Sreenivasaprasad S, Brown AE (1992) Detection and differentiation of Colletotrichum gloeosporioides isolates using PCR. FEMS Microbiol Lett 98: 137-143. https://doi.org/10.1111/j.15746968.1992.tb05503.x

Mo J, Zhao G, Li Q, Solangi G, Tang L, Huang S et al. (2018). Identification and characterization of Colletotrichum species associated with mango anthracnose in Guangxi, China. Plant Dis 102. https://doi.org/10.1094/PDIS-09-17-1516-RE

N Ziogas B, Nikou D, N Markoglou A, A Malandrakis A, Vontas J (2009) Identification of a novel point mutation in the $\beta$-tubulin gene of Botrytis cinerea and detection of benzimidazole resistance by a diagnostic PCR-RFLP assay. Eur J Plant Pathol 125: 97-107. https://doi.org/10.1007/s10658-009-9462-y

Nagaraju R, Sriram R, Achur R (2019) Antifungal activity of carbendazim-conjugated silver nanoparticles against anthracnose disease caused by Colletotrichum gloeosporioides in mango. Plant Pathol J 102: 39-46. https://doi.org/10.1007/s42161-019-00370-y

Nalumpang S, Miyamoto Y, Miyake C, Izumi Y, Akitmitsu K, Kongtragoul P (2010) Point mutations in the beta-tubulin gene conferred carbendazim-resistant phenotypes of Colletotrichum gloeosporioides causing 'Nam Dok Mai’ mango anthracnose. J Agric Sci Technol 6: 365-378. 
National Center for Biotechnology Information (2017) Restriction Fragment Length Polymorphism (RFLP). https://www.ncbi.nlm.nih.gov/probe/docs/techrflp/. Accessed 3 January 2020

O'Donnell K, Cigelnik E (1997) Two divergent intragenomic rDNA ITS2 types within a monophyletic lineage of the fungus Fusarium are nonorthologous. Mol Phylogenet 7: 103-116. https://doi.org/10.1006/mpev. $\underline{1996.0376}$

Peres NAR, Souza NL, Peever TL, Timmer LW (2004) Benomyl sensitivity of isolates of Colletotrichum acutatum and C. gloeosporioides from citrus. Plant Dis 88: 125-130. https://doi.org/10.1094/PDIS $\underline{.2004 .88 .2 .125}$

Pérez-López E, Olivier CY, Luna-Rodríguez M, Dumonceaux TJ (2016) Phytoplasma classification and phylogeny based on in silico and in vitro RFLP analysis of cpn60 universal target sequences. Int. J. Syst. Evol 66: 5600-5613. https://doi.org/10.1099/ijsem.0.001501

Phoulivong S, Cai L, Chen H, McKenzie EHC, Abdelsalam K, Chukeatirote E, Hyde KD (2010) Colletotrichum gloeosporioides is not a common pathogen on tropical fruits. Fungal Divers 44: 33-43. https://doi. org/10.1007/s13225-010-0046-0

Pongpisutta R, Winyarat W, Rattanakreetakul C (2013) RFLP identification of Colletotrichum species isolated from chilli in Thailand. Acta Hortic 973: 181-186. https://doi.org/10.17660/ActaHortic.2013.973.24

Poti T, Mahawan K, Cheewangkoon R, Arunothayanan H, Akimitsu K, Nalumpang S (2020) Detection and molecular characterization of carbendazim-resistant Colletotrichum truncatum Isolates causing anthracnose of soybean in Thailand. J Phytopathol 168: 267-278. https://doi.org/10.1111/jph.12888

Prihastuti H, McKenzie E, Hyde K, Cai L, Chen H, McKenzie EHC, Hyde KD (2009) Characterization of Colletotrichum species associated with coffee berries in northern Thailand. Fungal Divers 39: 89-109.

Qiu J, Xu J, Yu J, Bi C, Chen C, Zhou M (2011) Localization of the benzimidazole fungicide binding site of Gibberella zeae 32-tubulin studied by site-directed mutagenesis. Pest Manag Sci 67: 191-198. https://doi.org/10.1002/ps.2050

Ramdeen S, Rampersad SN (2013) Intraspecific differentiation of Colletotrichum gloeosporioides sensu lato based on in silico multilocus PCR-RFLP fingerprinting. Mol Biotechnol 53: 170-181. https://doi.org/10.1007/s12033-012-9509-8

Rosenzweig N, Hanson LE, Clark G, Franc GD, Stump WL, Jiang Q, et al. (2015) Use of PCR-RFLP analysis to monitor fungicide resistance in Cercospora beticola populations from Sugarbeet (Beta vulgaris) in Michigan, United States. Plant Dis 99: 355-362. https://doi.org/10.1094/PDIS-03-14-0241-RE

Rungjindamai N (2016) Isolation and evaluation of biocontrol agents in controlling anthracnose disease of mango in Thailand. J Plant Prot Res 56: 306-311. https://doi.org/10.1515/jppr-2016-0034

Sangchote S (2013) Integrated control of anthracnose (Colletotrichum gloeosporioides) of mango for export. Acta Hortic 973: 55-58. https://doi.org/10.17660/ActaHortic.2013.973.5

Sangchote S (1987) Postharvest diseases of mango fruits and their losses. Kasetsart Journal-Natural Sciences 21: 81-85.

Sreenivasaprasad S, Sharada K, Brown AE, Mills PR (1996) PCR-based detection of Colletotrichum acutatum on strawberry. Plant Pathol 45: 650-655. https://doi.org/10.1046/j.1365-3059.1996.d01-3.X

Sutton BC (1980) The Coelomycetes: fungi imperfecti with pycnidia, acervuli and stromata. Kew, UK 
Tamura K, Peterson D, Peterson N, Stecher G, Nei M, Kumar S (2011) MEGA5: Molecular evolutionary genetics analysis using maximum likelihood, evolutionary distance, and maximum parsimony methods. Mol Biol Evol 28: 2731-2739. https://doi.org/10.1093/molbev/msr121

Than PP, Jeewon R, Hyde KD, Pongsupasamit S, Mongkolporn O, Taylor PWJ (2008) Characterization and pathogenicity of Colletotrichum species associated with anthracnose on chilli (Capsicum spp.) in Thailand. Plant Pathol 57: 562-572. https://doi.org/10.1111/j.1365-3059.2007.01782.x

Thompson JD, Higgins DG, Gibson TJ (1994) CLUSTAL W: improving the sensitivity of progressive multiple sequence alignment through sequence weighting, position-specific gap penalties and weight matrix choice. Nucleic Acids Res 22: 4673-4680. https://doi.org/10.1093/nar/22.22.4673

Tredway L, Wong F (2012) Managing anthracnose with fungicides. https://www.gcsaa.org/uploadedfiles/course /pests-and-diseases/diseases/anthracnose/managing-anthracnose-with-fungicides.pdf. Accessed 1 March 2020

Walker J, Nikandrow A, Millar GD (1991) Species of Colletotrichum on Xanthium (Asteraceae) with comments on some taxonomic and nomenclatural problems in Colletotrichum. Mycol Res 95:1175-1193. https://doi.org/10.1016/S0953-7562(09)80008-7

Wei W, Davis RE, Lee I-M, Zhao Y (2007) Computer-simulated RFLP analysis of 16S rRNA genes: identification of ten new phytoplasma groups. Int J Syst Evol 57: 1855-1867. https://doi.org/10.1099/ijs.0.65000-0

Weir BS, Johnston PR, Damm U (2012) The Colletotrichum gloeosporioides species complex. Stud Mycol 73: 115-180. https://doi.org/10.3114/sim0011

White T.J, Bruns T, Lee S, Taylor J (1990) Amplification and direct sequencing of fungal ribosomal RNA genes for phylogenetics. In MA Innis, DH Gelfand, J Sninsky, TJ White (Eds.), PCR protocols: A guide to method and application (pp. 315-322). New York, US

Worldatlas (2019) The top mango producing countries in the world. https://www.worldatlas.com/articles/thetop-mango-producing-countries-in-the-world.html. Accessed 3 January 2020

Zakaria L (2021) Diversity of Colletotrichum species associated with anthracnose disease in tropical fruit Crops-A review. Agriculture 11: 297. https://doi.org/10.3390/agriculture11040297

Zhan JS, Wu EJ, Liuand XL, Chen FP (2014) Molecular basis of resistance of phytopathogenic fungi to several site-specific fungicides. Sci Agric Sin, 47: 3392-3404. https://doi.org/10.3864/j.issn.0578-1752.2014.17.007

Zhou Y, Xu J, Zhu Y, Duan Y, Mingguo Z (2016) Mechanism of action of the benzimidazole fungicide on Fusarium graminearum: interfering with polymerization of monomeric tubulin but not polymerized microtubule. Phytopathology 106. https://doi.org/10.1094/PHYTO-08-15-0186-R

Zimand G, Valinsky L, Elad Y, Chet I, Manulis S (1994) Use of the RAPD procedure for the identification of Trichoderma strains. Mycol Res 98: 531-534. https://doi.org/10.1016/S0953-7562(09)80474-7

(1)

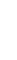

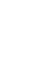

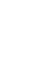


Table 1. Primers used in this study with sequences and sources.

596

597

\begin{tabular}{|l|l|l|c|l|}
\hline \multicolumn{1}{|c|}{ Gene/Region } & \multicolumn{1}{|c|}{ Primer } & \multicolumn{1}{|c|}{ Sequence (5'-3') } & Ta $\left({ }^{\circ} \mathbf{C}\right)$ & \multicolumn{1}{c|}{ References } \\
\hline Actin & ACT-512F & ATGTGCAAGGCCGGTTCGC & 58 & Carbone and Kohn (1999) \\
\hline & ACT-783R & TACGAGTCCTTCTGGCCCAT & & \\
\hline Chitin Synthase 1 & CHS-79F & TGGGGCAAGGATGCTTGGAAGAAG & 58 & Carbone and Kohn (1999) \\
\hline & CHS-345R & TGGAAGAACCATCTGTGAGAGTTG & & \\
\hline ITS region & ITS5 & GGAAGTAAAAGTCGTAACAAGG & 56 & White et al. (1990) \\
\hline & ITS4 & TCCTCCGCTTATTGATATGC & & \\
\hline$\beta$-tubulin & T1 & AACATGCGTGAGATTGTAAGT & 55 & O'Donnell and Cigelnik (1997) \\
\hline & T2 & TAGTGACCCTTGGCCCAGTTG & & \\
\hline Ca-specific primer & CaInt & GGGGAAGCCTCTCGCGG & 58 & Sreenivasaprasad et al. (1996) \\
\hline & ITS4 & TCCTCCGCTTATTGATATGC & & White et al. (1990) \\
\hline$C g$-specific primer & CgInt & GGCCTCCCGCCTCCGGGCGG & 57.2 & Mills et al. (1992) \\
\hline & ITS4 & TCCTCCGCTTATTGATATGC & & White et al. (1990) \\
\hline
\end{tabular}

598

599

600

601

602

603

\begin{tabular}{|c|c|c|}
\hline Levels & Colony diameters & Resistant levels \\
\hline- & $6.00 \mathrm{~mm}$ & Highly sensitive (HS) \\
\hline+ & $7.00-10.00 \mathrm{~mm}$ & Sensitive (S) \\
\hline++ & $11.00-14.00 \mathrm{~mm}$ & Resistant (R) \\
\hline+++ & $15.00 \mathrm{~mm}$ & Highly resistant (HR) \\
\hline
\end{tabular}

604

605

606

607

608

609

610

611

612

613

614

615

616 
Table 3. Details of Colletotrichum species taxa used in the phylogenetic analysis and all isolates collected from mango anthracnose disease

\begin{tabular}{|c|c|c|c|c|c|c|}
\hline \multirow{2}{*}{ Species } & \multirow{2}{*}{ Isolate/Culture } & \multicolumn{4}{|c|}{ GenBank accession numbers ${ }^{1}$} & \multirow{2}{*}{ References } \\
\hline & & $\mathbf{A C T}^{2}$ & CHS-1 ${ }^{2}$ & ITS $^{2}$ & TUB $^{2}$ & \\
\hline \multirow[t]{14}{*}{ C. asianum } & ICMP18580, CBS130418 & JX009584 & JX009867 & FJ972612 & JX010406 & Wei et al. (2012) \\
\hline & IMI313839, ICMP18696 & JX009576 & JX009753 & JX010192 & JX010384 & Wei et al. (2012) \\
\hline & MAFF306627, ICMP18603 & JX009579 & JX009825 & JX010195 & $\cdots$ & Wei et al. (2012) \\
\hline & HKUCC10862, ICMP18605 & JX009465 & JX009787 & JX010194 & $\ldots$ & Wei et al. (2012) \\
\hline & RB001 & LC616858 & LC618309 & MK215695 & LC635528 & This study \\
\hline & RB005 & LC616859 & LC618310 & MK215689 & LC635529 & This study \\
\hline & RB007 & LC618294 & LC618311 & MK215692 & LC635530 & This study \\
\hline & RB010 & LC618295 & LC618312 & MK215694 & LC635531 & This study \\
\hline & RB011 & LC618296 & LC618313 & MK215701 & LC635532 & This study \\
\hline & RB012 & LC618297 & LC618314 & MK215700 & LC635533 & This study \\
\hline & PC001 & LC618298 & LC618315 & MK212353 & LC635534 & This study \\
\hline & PC003 & LC618299 & LC618316 & MK212354 & LC635535 & This study \\
\hline & PC004 & LC618300 & LC618317 & MK215703 & LC635536 & This study \\
\hline & PC005 & LC618301 & LC618318 & MK215686 & LC635537 & This study \\
\hline \multirow[t]{8}{*}{ C. gloeosporioides } & ICMP17821, CBS112999 & JX009531 & JX009818 & JX010152 & JX010445 & Wei et al. (2012) \\
\hline & ICMP18694 & JX009481 & JX009796 & JX010155 & $\ldots$ & Wei et al. (2012) \\
\hline & ICMP12939 & JX009462 & JX009747 & JX010149 & $\ldots$ & Wei et al. (2012) \\
\hline & ICMP18730 & JX009548 & JX009861 & JX010157 & $\ldots$ & Wei et al. (2012) \\
\hline & CS001 & $\cdots$ & $\cdots$ & MK128499 & LC628900 & This study \\
\hline & $\mathrm{CSOO2}$ & $\cdots$ & $\cdots$ & MK212348 & LC628901 & This study \\
\hline & $\mathrm{CSO03}$ & $\ldots$ & $\ldots$ & MK212349 & LC628902 & This study \\
\hline & $\mathrm{CSO04}$ & $\ldots$ & $\ldots$ & MK212350 & LC628903 & This study \\
\hline
\end{tabular}




\begin{tabular}{|c|c|c|c|c|c|c|}
\hline & CS005 & $\ldots$ & $\ldots$ & MK212351 & LC628904 & This study \\
\hline & CS006 & $\ldots$ & $\ldots$ & MK215702 & LC628905 & This study \\
\hline & CSO07 & $\ldots$ & $\ldots$ & MK215691 & LC628906 & This study \\
\hline & CSO08 & LC618302 & LC618321 & MK212352 & LC628907 & This study \\
\hline & CS009 & $\ldots$ & $\ldots$ & MK215693 & LC628908 & This study \\
\hline & CS010 & $\ldots$ & $\ldots$ & MK215704 & LC628909 & This study \\
\hline & RB002 & $\ldots$ & $\ldots$ & MK212942 & LC635519 & This study \\
\hline & RB004 & LC618303 & LC618322 & MK215698 & LC635520 & This study \\
\hline & RB008 & $\ldots$ & $\ldots$ & MK212948 & LC635521 & This study \\
\hline & RB009 & $\ldots$ & $\ldots$ & MK212947 & LC635522 & This study \\
\hline & RB013 & $\ldots$ & $\ldots$ & MK215707 & LC635523 & This study \\
\hline & RB015 & $\ldots$ & $\ldots$ & MK215705 & LC635524 & This study \\
\hline & PC008 & $\ldots$ & $\ldots$ & MK215687 & LC635525 & This study \\
\hline & PC009 & LC618304 & LC618323 & MK215697 & LC635526 & This study \\
\hline & $\mathrm{PC} 010$ & $\ldots$ & $\ldots$ & MK215696 & LC635527 & This study \\
\hline \multirow[t]{7}{*}{ C. siamense } & ICMP12567 & JX009541 & JX009761 & JX010250 & JX010387 & Wei et al. (2012) \\
\hline & ICMP18578, CBS130417 & FJ907423 & JX009865 & JX010171 & JX010404 & Wei et al. (2012) \\
\hline & HKUCC10884, ICMP18575 & JX009455 & JX009785 & JX010256 & $\ldots$ & Wei et al. (2012) \\
\hline & HKUCC10881, ICMP18618 & JX009512 & JX009786 & JX010257 & $\ldots$ & Wei et al. (2012) \\
\hline & RB003 & LC618305 & LC618319 & MK212943 & LC635538 & This study \\
\hline & RB006 & $\ldots$ & $\ldots$ & MK215699 & LC635539 & This study \\
\hline & $\mathrm{PC} 002$ & LC618306 & LC618320 & MK212355 & LC635540 & This study \\
\hline \multirow[t]{4}{*}{ C. acutatum } & CBS144.29 & JQ949722 & JQ949062 & JQ948401 & JQ950052 & Damm et al. (2012a) \\
\hline & CBS112996, STE-U5292 & JQ005839 & JQ005797 & JQ005776 & JQ005860 & Damm et al. (2012a) \\
\hline & CBS111993, STE-U3037 & JQ949670 & JQ949010 & JQ948349 & JQ950000 & Damm et al. (2012a) \\
\hline & CBS112760, STE-U4468 & JQ949713 & JQ949053 & JQ948392 & JQ950043 & Damm et al. (2012a) \\
\hline
\end{tabular}




\begin{tabular}{|l|l|l|l|l|l|l|}
\hline C. tropicale & MAFF239933, ICMP18672 & JX009480 & JX009826 & JX010275 & JX010396 & Wei et al. (2012) \\
\hline & CBS124949, ICMP18653 & JX009489 & JX009870 & JX010264 & JX010407 & Wei et al. (2012) \\
\hline C. fructicola & CBS125395, ICMP18645 & JX009543 & JX009873 & JX010172 & JX010408 & Wei et al. (2012) \\
\hline & ICMP18581, CBS130416 & JX009501 & JX009866 & JX010165 & JX010405 & Wei et al. (2012) \\
\hline C. nymphaeae & CBS129926, CPC18719 & JQ949537 & JQ948877 & JQ948216 & JQ949867 & Damm et al. (2012a) \\
\hline & CBS515.78 & JQ949518 & JQ948858 & JQ948197 & JQ949848 & Damm et al. (2012a) \\
\hline C. simmondsii & CBS122122, BRIP28519 & JQ949597 & JQ948937 & JQ948276 & JQ949927 & Damm et al. (2012a) \\
\hline C. theobromicola & IMI313840, CPC18875 & JQ949605 & JQ948945 & JQ948284 & JQ949935 & Damm et al. (2012a) \\
\hline C. boninense & ICMP18567 & JX009457 & JX009803 & JX010287 & JX010377 & Wei et al. (2012) \\
\hline & ICMP17895 & JX009568 & JX009828 & JX010284 & JX010382 & Wei et al. (2012) \\
\hline & CBS128547, ICMP10338 & JQ005507 & JQ005333 & JQ005159 & JQ005593 & Damm et al. (2012b) \\
\hline
\end{tabular}

${ }^{1}$ BRIP: Plant Pathology Herbarium, Department of Employment, Economic, Development and Innovation, Queensland, Australia; CBS = CBS-KNAW, Fungal Biodiversity Centre, Utrecht, Netherlands; HKUCC: The University of Hong Kong Culture Collection, Hong Kong, China; ICMP = International Collection of Microorganisms from Plant, Landcare Research, Auckland, New Zealand; IMI = Culture collection of CABI Europe UK Centre, Egham, UK; MAFF: MAFF Genebank Project, Ministry of Agriculture, Forestry and Fisheries, Tsukuba, Japan; PD: Plantenziektenkundige Dienst Wageningen, the Netherland; STE-U: Culture collection of the Department of Plant Pathology, University of Stellenbosch, South Africa.

${ }^{2} \mathrm{ACT}=$ actin gene $;$ CHS $-1=$ chitin synthase $; \mathrm{ITS}=$ rDNA internal transcribed spacer region; TUB2 $=\beta$-tubulin 
Table 4. Incidence of infection on mango cv. Nam Dork Mai See Tong fruits and leaves by Colletotrichum various species.

\begin{tabular}{|l|c|c|c|c|}
\hline \multirow{2}{*}{ Fungal species } & \multicolumn{2}{c|}{ Infection incidence $(\%)$} & \multicolumn{2}{c|}{ Disease severity $(\mathbf{c m})$} \\
\cline { 2 - 4 } & Fruits & Leaves & Fruits & Leaves \\
\hline C. asianum & 75 & 100 & $3.93 \mathrm{ab}$ & $2.45 \mathrm{ab}$ \\
\hline C. gloeosporioides & 100 & 100 & $4.28 \mathrm{a}$ & $2.89 \mathrm{a}$ \\
\hline C. siamense & 60 & 100 & $3.48 \mathrm{~b}$ & $1.75 \mathrm{~b}$ \\
\hline
\end{tabular}

Table 5. Level of carbendazim resistance and point mutations at different codons in the $\beta$-tubulin gene of 3 species of Colletotrichum causing mango anthracnose disease.

\begin{tabular}{|c|c|c|c|c|c|c|c|}
\hline \multirow[t]{2}{*}{ Species } & \multirow[t]{2}{*}{ Isolate } & \multirow{2}{*}{$\begin{array}{c}\mathrm{MIC} \\
(\mu \mathrm{g} / \mathrm{L})\end{array}$} & \multirow{2}{*}{$\begin{array}{c}\text { Resistance } \\
\text { level }\end{array}$} & \multicolumn{4}{|c|}{ Position of Genotype (bp) } \\
\hline & & & & 167 & 198 & 200 & 240 \\
\hline \multirow[t]{10}{*}{ C. asianum } & RB001 & $>1,000$ & HR & TTC (F) & GCG (A) & TTC $(\mathrm{F})$ & $\mathrm{CTG}(\mathrm{L})$ \\
\hline & RB005 & $>1,000$ & HR & TTC (F) & GCG (A) & TTC (F) & $\mathrm{CTG}(\mathrm{L})$ \\
\hline & RB007 & $>1,000$ & HR & TTC (F) & GCG (A) & TTC $(\mathrm{F})$ & $\mathrm{CTG}(\mathrm{L})$ \\
\hline & RB010 & $>1,000$ & HR & TTC (F) & GCG (A) & TTC (F) & CTG (L) \\
\hline & RB011 & 100 & $\mathrm{R}$ & TTC (F) & GAG (E) & TAC (Y) & CTG (L) \\
\hline & RB012 & $>1,000$ & HR & TTC (F) & GCG (A) & TTC (F) & $\mathrm{CTG}(\mathrm{L})$ \\
\hline & $\mathrm{PC} 001$ & $>1,000$ & HR & TTC (F) & GCG (A) & TTC (F) & $\mathrm{CTG}(\mathrm{L})$ \\
\hline & $\mathrm{PC} 003$ & $>1,000$ & HR & TTC (F) & GCG (A) & TTC (F) & CTG (L) \\
\hline & $\mathrm{PC} 004$ & $>1,000$ & HR & TTC (F) & GCG (A) & TTC (F) & CTG (L) \\
\hline & PC005 & $>1,000$ & HR & TTC (F) & GCG (A) & TTC (F) & CTG (L) \\
\hline \multirow[t]{19}{*}{ C. gloeosporioides } & CS001 & 10 & $\mathrm{~S}$ & TTC (F) & GAG (E) & TTC (F) & $\mathrm{CTG}(\mathrm{L})$ \\
\hline & CSO02 & $>1,000$ & HR & TTC (F) & GCG (A) & TTC (F) & $\mathrm{CTG}(\mathrm{L})$ \\
\hline & CS003 & $>1,000$ & HR & TTC (F) & GCG (A) & TTC (F) & CTG (L) \\
\hline & CSO04 & 100 & $\mathrm{R}$ & TTC (F) & GAG (E) & TAC (Y) & CTG (L) \\
\hline & CSO05 & 100 & $\mathrm{R}$ & TTC (F) & GAG (E) & TAC (Y) & $\mathrm{CTG}(\mathrm{L})$ \\
\hline & CS006 & 10 & $\mathrm{~S}$ & TTC (F) & GAG $(\mathrm{E})$ & TTC (F) & $\mathrm{CTG}(\mathrm{L})$ \\
\hline & $\mathrm{CS} 007$ & 10 & $\mathrm{~S}$ & TTC (F) & GAG $(\mathrm{E})$ & TTC (F) & $\mathrm{CTG}(\mathrm{L})$ \\
\hline & CS008 & 10 & $S$ & TTC (F) & GAG (E) & TTC (F) & CTG (L) \\
\hline & CS009 & 10 & $\mathrm{~S}$ & TTC (F) & GAG (E) & TTC $(\mathrm{F})$ & CTG (L) \\
\hline & CS010 & 100 & $\mathrm{R}$ & TTC (F) & GAG (E) & TAC (Y) & CTG (L) \\
\hline & RB002 & $>1,000$ & HR & TTC (F) & GCG (A) & TTC (F) & CTG (L) \\
\hline & RB004 & 10 & $S$ & TTC (F) & GAG (E) & TTC (F) & CTG (L) \\
\hline & RB008 & 100 & $\mathrm{R}$ & TTC (F) & GAG (E) & TAC (Y) & CTG (L) \\
\hline & RB009 & 100 & $\mathrm{R}$ & TTC (F) & GAG (E) & TAC (Y) & CTG (L) \\
\hline & RB013 & $>1,000$ & $\mathrm{HR}$ & TTC (F) & GCG (A) & TTC (F) & $\mathrm{CTG}(\mathrm{L})$ \\
\hline & RB015 & $>1,000$ & $\mathrm{HR}$ & TTC (F) & GCG (A) & TTC (F) & $\mathrm{CTG}(\mathrm{L})$ \\
\hline & $\mathrm{PC} 008$ & $>1,000$ & HR & TTC (F) & GCG (A) & TTC (F) & $\mathrm{CTG}(\mathrm{L})$ \\
\hline & PC009 & $>1,000$ & HR & TTC (F) & GCG (A) & TTC (F) & CTG (L) \\
\hline & PC010 & $>1,000$ & HR & TTC (F) & GCG (A) & TTC (F) & CTG (L) \\
\hline \multirow[t]{3}{*}{ C. siamense } & RB003 & $>1,000$ & HR & TTC (F) & GCG (A) & TTC (F) & CTG (L) \\
\hline & RB006 & $>1,000$ & HR & TTC (F) & GCG (A) & TTC (F) & CTG (L) \\
\hline & $\mathrm{PC} 002$ & $>1,000$ & HR & TTC (F) & GCG (A) & TTC (F) & CTG (L) \\
\hline U14138 ${ }^{1}$ & - & - & $S$ & TTC (F) & GAG (E) & TTC (F) & CTG $(\mathrm{L})$ \\
\hline
\end{tabular}

${ }^{1}$ Buhr and Dickman (1993) 
Figure legends:

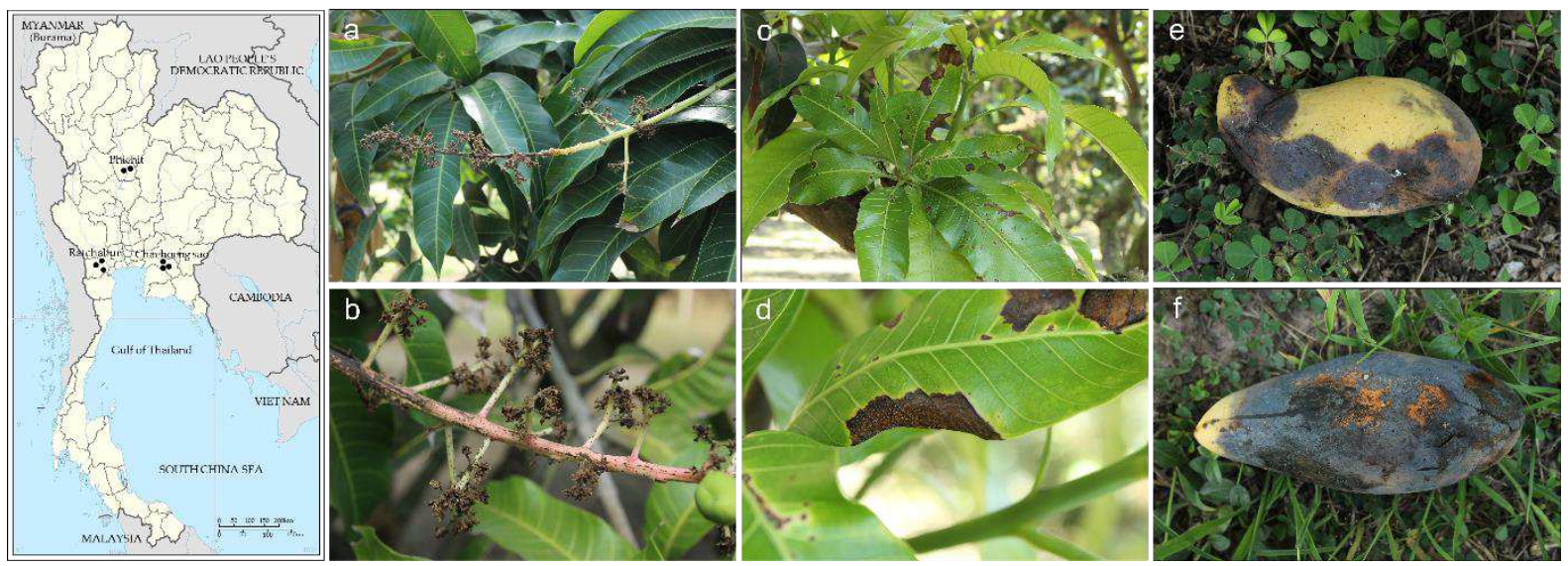

Fig. 1 Field symptoms of mango anthracnose caused by Colletotrichum spp. on the (a-b) inflorescences, (c-d) leaves and (e-f) fruits. 


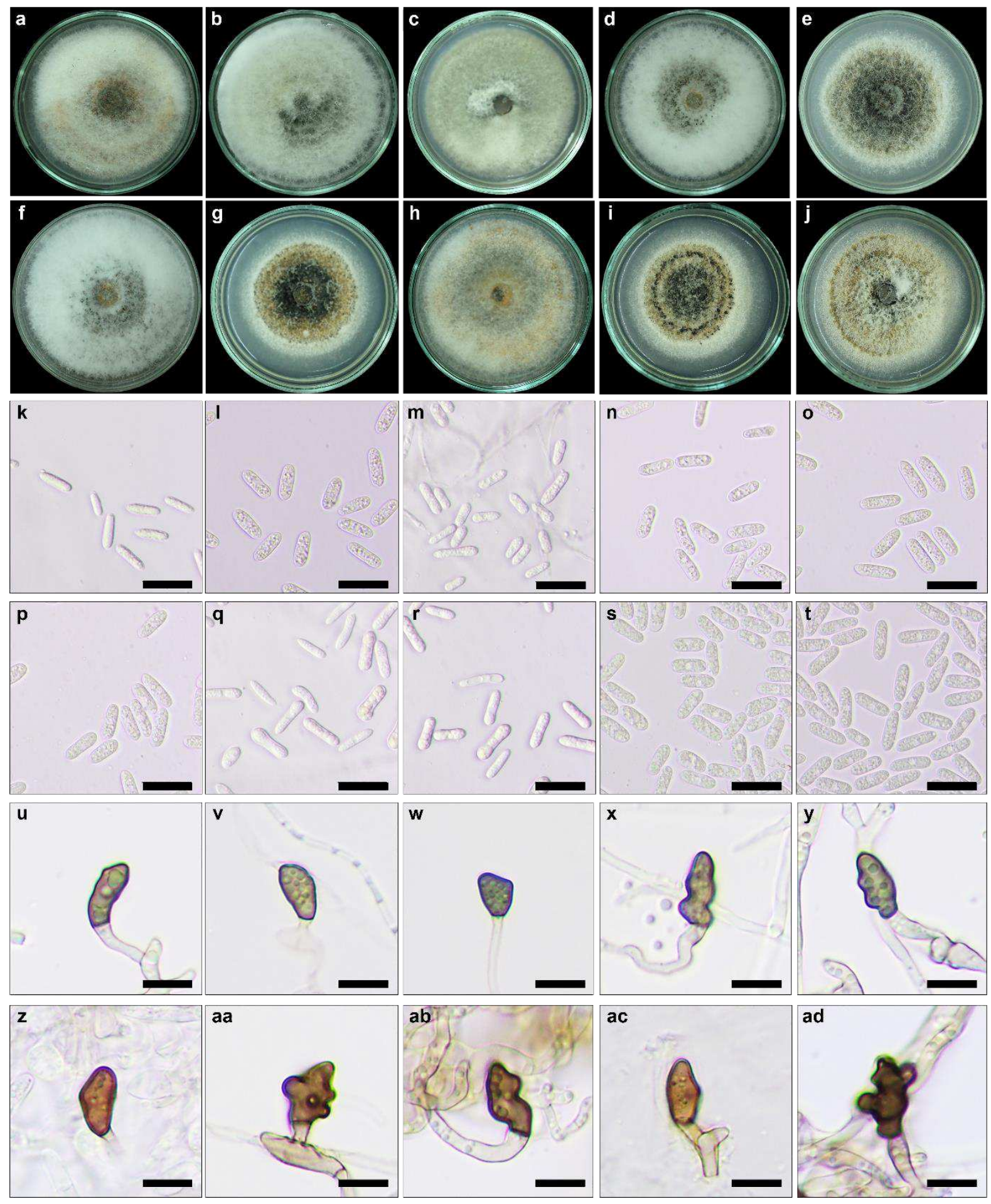

Fig. 2 Morphological characteristics of Colletotrichum from 3 plantation areas: (A-J) colony on PDA incubated at $25^{\circ} \mathrm{C}$ under a photoperiod of $12 \mathrm{hr}$ light / $12 \mathrm{hr}$ dark for 5 days, (K-T) cylindrical shape of Colletotrichum conidia, and (U-AD) several appressoria (Fig. S1) under a compound microscope at 400X (scale bar $=20 \mu \mathrm{m})$. 


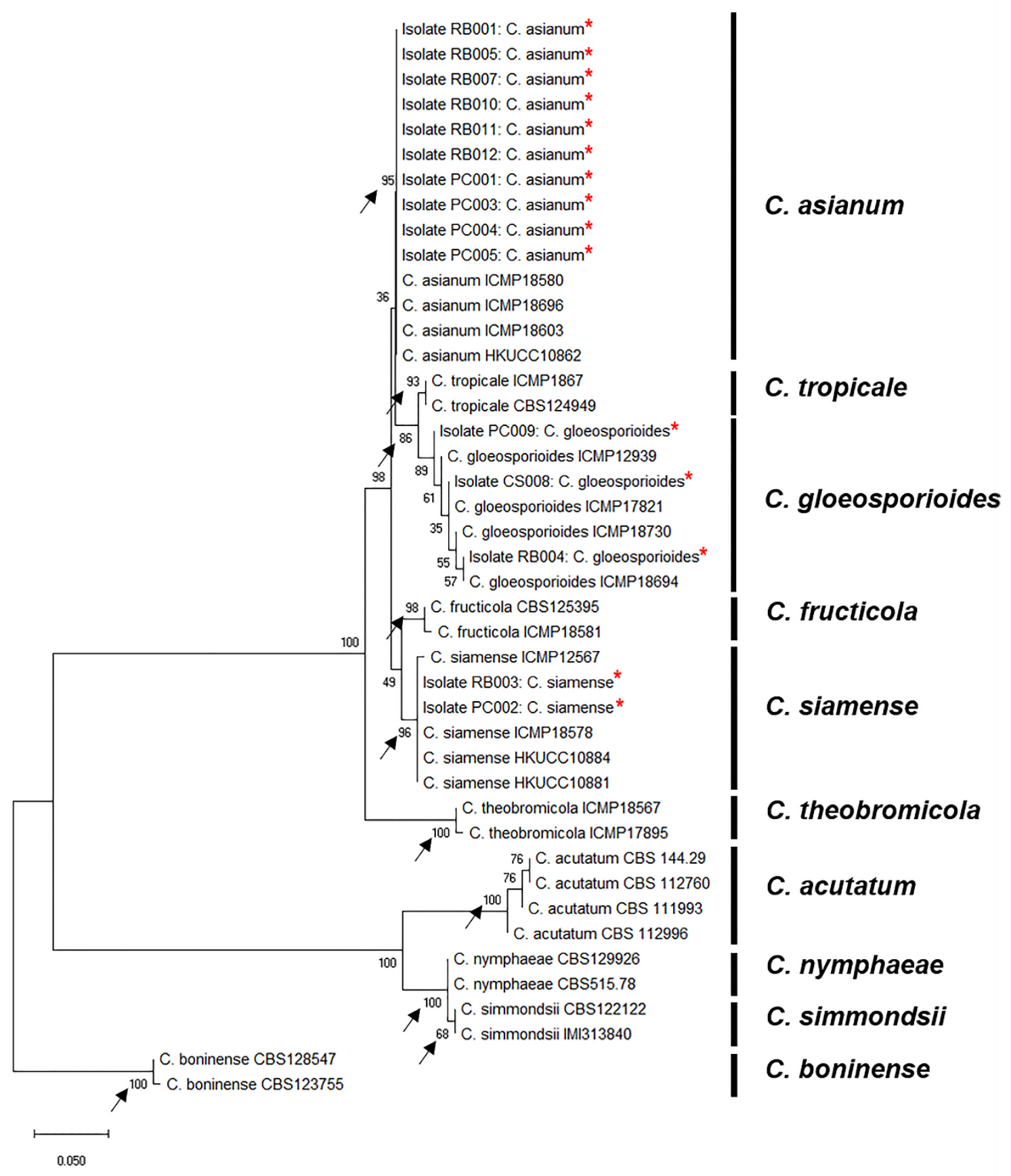

Fig. 3 A maximum likelihood phylogenetic tree of representative 15 isolates of the Colletotrichum species complex using the partial sequence data of the ACT gene, CHS-1 gene, ITS region and TUB gene (red asterisks). The percentage of replicate trees in which the associated taxa clustered together in the bootstrap test $(1,000$ replicates) is shown next to the branches at black arrows, and the evolutionary distances were computed using the Kimura 2-parameter model combined with a gamma distribution (G). All analyses were conducted in MEGA version $\mathrm{X}$ 


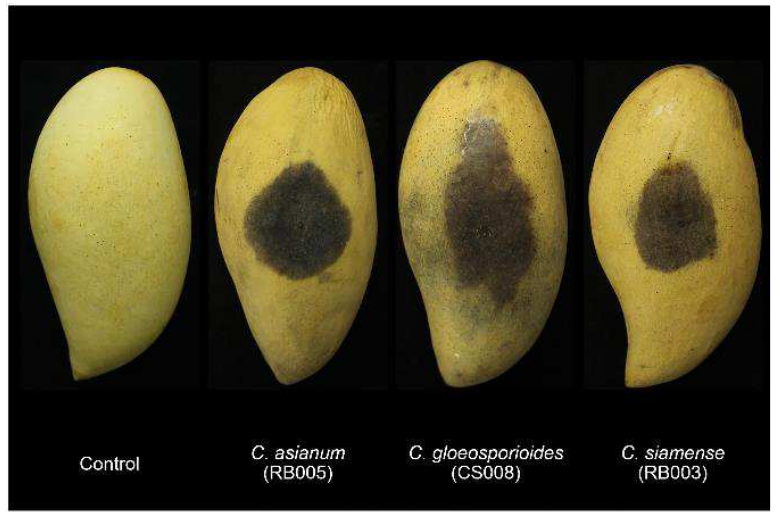

(a)

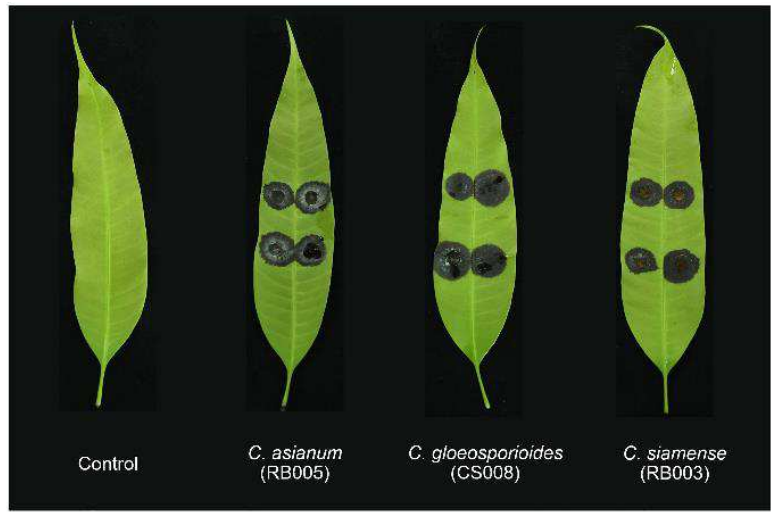

(b)

Fig. 4 Anthracnose symptoms on mango after inoculation with 3 species of Colletotrichum using unwounded technique on the (a) fruits and (b) leaves. 


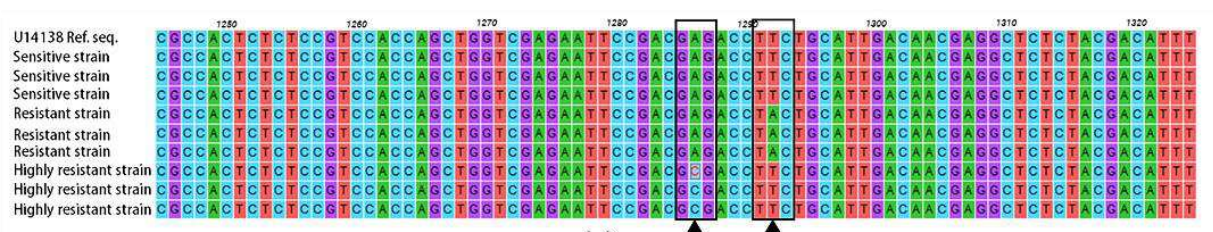

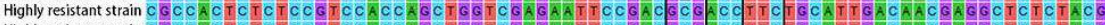

(a)

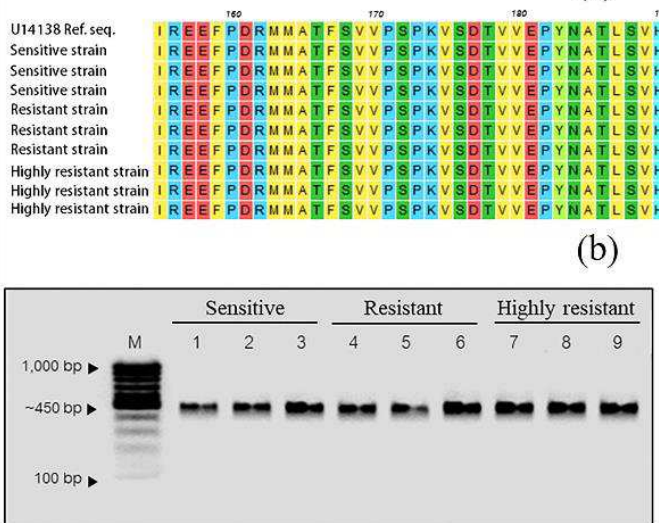

(c)

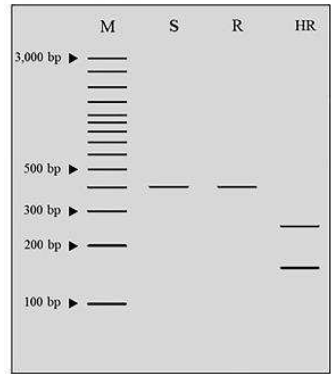

(d)

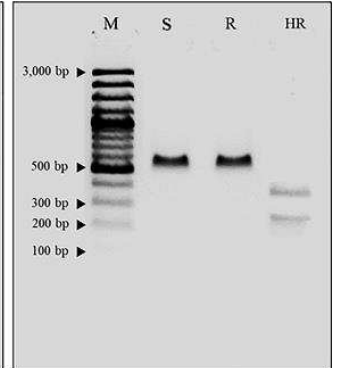

(e)

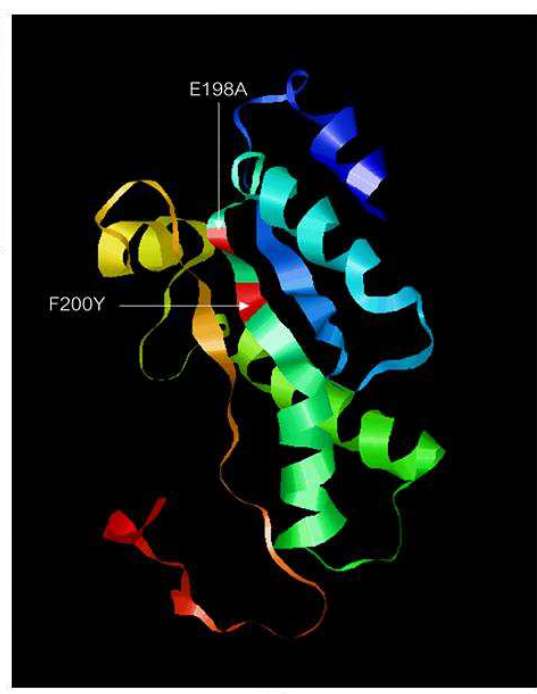

(f)

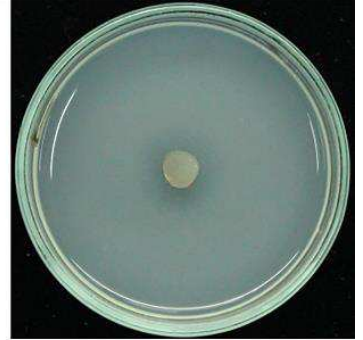

Sensitive strain

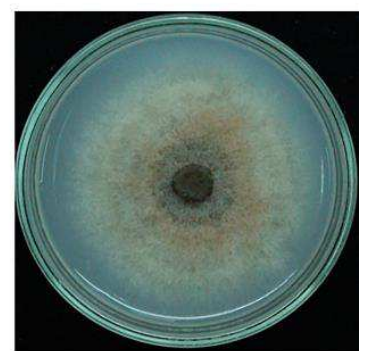

Resistant strain

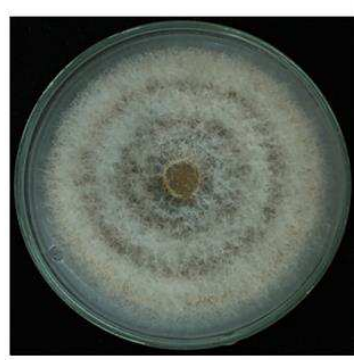

Highly resistant strain

Fig. 5 Molecular detection of carbendazim fungicide resistance. (a) Partial $\beta$-tubulin sequences of 9 isolates amplified with TB2L/TB2R and compared with the reference sequence U14138 (C. gloeosporioides f. sp. aeschynomene), (b) Partial protein sequences of 9 isolates aligned with the reference sequence U14138 (colored according to the protein setting in MEGA version X), (c) PCR products subjected to $1.2 \%$ agarose gel electrophoresis, (d) Simulated digested products produced via in silico restriction digestion using by pDRAW3.2 with Bsh1236I, (e) Bsh1236I-digested product that distinguished between S and R strains, and (f) Secondary structure of $\beta$-tubulin; the arrows indicate codons 198 and 200. 


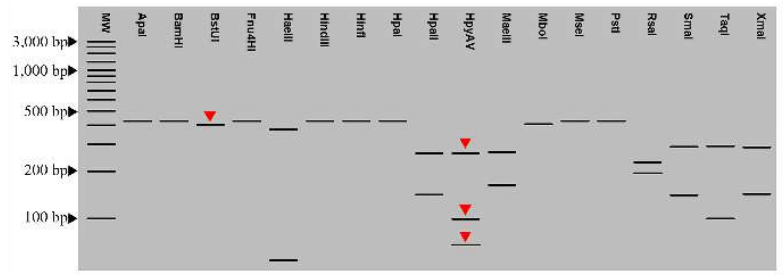

(a)

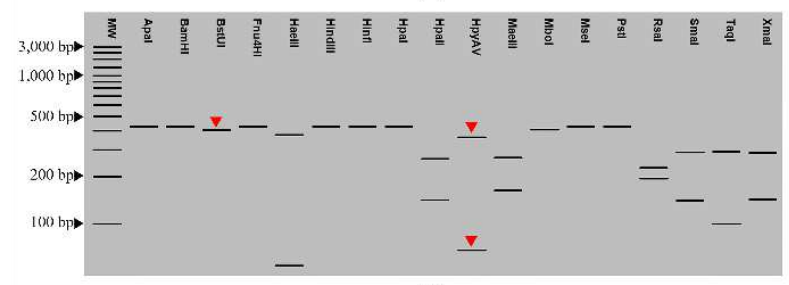

(b)

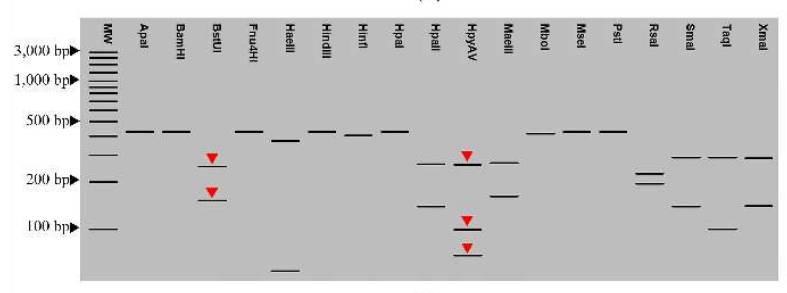

(c)

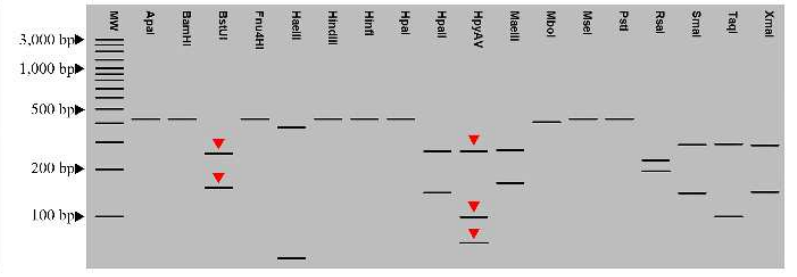

(d)

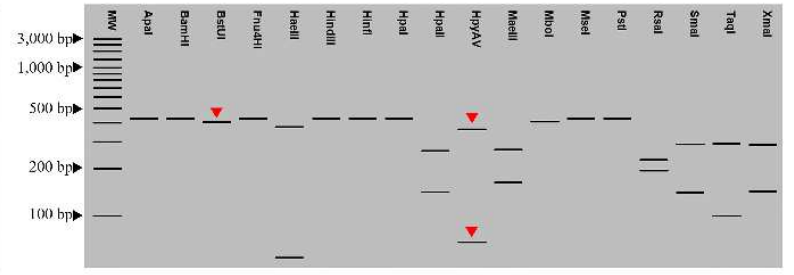

(e)

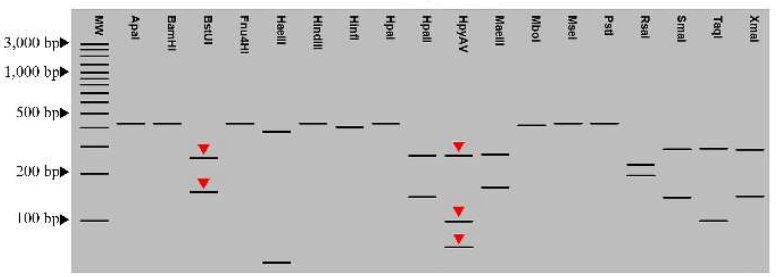

(f)

Fig. 6 Virtual RFLP gel electrophoresis pattern derived from in silico digestion of partial the $\beta$-tubulin gene sequence using pDRAW32 software. In the computer-simulated digestions, the full set of eighteen representative enzymes: ApaI, BamHI, BstUI, Fnu4HI, HaeIII, HindIII, HinfI, HpaI, HpaII, HpyAV, MaeIII, MboI, MseI, PstI, RsaI, SmaI, TaqI and XmaI were used. MW is Fermentas 100 bp Plus DNA Ladder. (a) C. gloeosporioides - S strain, (b) C. gloeosporioides - R strain, (c) C. gloeosporioides - HR strain, (d) C. siamense - HR strain, (e) C. asianum - R strain, and (f) C. asianum - HR strain. 


\section{Supplementary Files}

This is a list of supplementary files associated with this preprint. Click to download.

- Supplementaryinformation.pdf 